\title{
The supply of nitrogen fertilizer in wheat to the highest environmental quality with satisfactory yield
}

\author{
A.P.B. Trautmann ${ }^{1}$, J.A.G. da Silva ${ }^{1}$, J.A. da Rosa $^{1}$, I.R. Carvalho ${ }^{1}$, \\ F. Lautenchleger ${ }^{2}$, C.F. Colet ${ }^{1}$, M.S. Jung ${ }^{1}$, E. Warmbier ${ }^{1}$, N.C.F Basso ${ }^{1}$, \\ A.K. Polanczyk and C.V. Argenta ${ }^{1}$ \\ ${ }^{1}$ Universidade Regional do Noroeste do Estado do Rio Grande do Sul, Ijuí, \\ RS, Brasil \\ ${ }^{2}$ Universidade Estadual do Centro-Oeste, Guarapuava, PR, Brasil \\ Corresponding author: I.R. Carvalho \\ E-mail: carvalho.irc@gmail.com
}

Genet. Mol. Res. 20 (3): gmr18903

Received May 05, 2021

Accepted June 20, 2021

Published July 29, 2021

DOI http://dx.doi.org/10.4238/gmr18903

\begin{abstract}
The management of nitrogen in wheat based on biological and environmental indicators can ensure productivity with a reduction in environmental impact. The objective of the study was to develop a more sustainable management of nitrogen use in wheat, considering the dose as a fraction of the total supply based on an estimate of the maximum technical and economic efficiency, and expected grain yield, in systems of succession of high and reduced release of N-residual, during acceptable and unfavorable crop years. The study was conducted from 2012 to 2018, in Augusto Pestana, RS, Brazil. Two experiments were conducted in each agricultural year and in each rotation system (soybean/wheat and corn/wheat), one to quantify the biomass yield and the other to determine grain yield. The experimental design was a randomized block with four repetitions in a $5 \times 3$ factorial, for doses of $\mathrm{N}$-fertilizer $(0,30,60,90$, $120 \mathrm{~kg} \mathrm{ha}^{-1}$ ) and ways of supplying the nutrient [full condition $(100 \%)$ at the phenological stage $\mathrm{V}_{3}$ (third expanded leaf); fractionated $(70 \% / 30 \%)$ at phenological stage $\mathrm{V}_{3} / \mathrm{V}_{6}$ (third and sixth expanded leaf) and fractionated $(70 \% / 30 \%)$ at phenological stage $\mathrm{V}_{3} / \mathrm{R}_{1}$ (third expanded leaf and ear differentiation)], in the
\end{abstract}


soybean/wheat and corn/wheat succession systems with high and reduced N-residual release, respectively. More efficient use of nitrogen was obtained based on wheat grain productivity when applied at the full dose at the third expanded leaf stage. The supply of the maximum dose of nitrogen with an expectation of $3 \mathrm{tha}^{-1}$ ensures satisfactory productivity with reduced nutrient losses to the environment, especially in unfavorable years for cultivation, regardless of the succession system.

Key words: Triticum aestivum; Succession systems; Meteorological condition; Regression; Sustainability

\section{INTRODUCTION}

The wheat (Triticum aestivum) crop is of great food and economic importance in national and world markets. In Brazil, it is the main winter cereal grown, reaching an area of 2 million hectares and an estimated production of 4.9 million tons in 2019 (Vasconcellos et al., 2018; Carvalho et al., 2019). It is a crop with various purposes, being used in the provision of forage in periods of scarcity of native fields and in crop rotation systems, as well as for the production of grains for human and animal consumption, with high nutritional quality (Ronsani et al., 2018; Mammann et al., 2019). Wheat grain is a raw material for the preparation of foods that are part of the base of the food pyramid, with consumption strongly encouraged by the Food Guide for the Brazilian Population (Goergen et al., 2017; Costa et al., 2018).

Currently, there is a need to produce better quality food, minimize operating costs, reduce soil movement, combine less polluting technologies and combine meteorological factors with management in agroecosystems, (Camponogara et al., 2016; Mammann et al., 2020). Among the inputs used in agriculture, nitrogen fertilizers are the ones that most burden and pollute soil and water, with high production costs and reduced efficiency due to volatilization and leaching losses (Arenhardt et al., 2017; Petean et al., 2019). The high demand for nitrogen in non-leguminous crops such as corn, wheat and rice, generates a demand of almost 50\% of all nitrogen fertilizer produced in the world (Tasca et al., 2011; Ladha et al., 2016). Depending on weather and soil conditions during management, studies even comment on losses of more than $78 \%$ of the nutrient applied to plants (Tasca et al., 2011; Vieira, 2017). The manufacture and application of nitrogen fertilizers in agriculture also contribute to the emission of gases $\left(\mathrm{CO}_{2}\right.$ and $\left.\mathrm{NO}_{2}\right)$ that collaborate to increase the planet's temperature (Wick et al., 2012; Xu et al., 2012).

Studies that enable technologies to reverse and/or minimize nitrogen losses to the environment and generate satisfactory grain productivity with greater sustainability, are decisive in today's agriculture that seeks technical, economic and environmental efficiency (Scremin et al., 2017; Luche et al., 2017). Thus, strategies to increase the efficiency of nitrogen use in wheat growing are being increasingly sought after, evidencing the need to relate the way of supplying the nutrient in full or fractional doses, along with biological responses in successions systems and meteorological conditions during species growing. Therefore a condition that can optimize the relationship between nutrient management and 
grain production in order to obtain satisfactory yields with reduced loss of nutrient to the environment in the promotion of higher environmental quality.

The objective of the study was to develop a more sustainable management of nitrogen use, considering the dose with the total and fractionated supply by the estimate of the maximum technical and economic efficiency, and expected grain yield, in the succession systems of high and reduced N-residual release and favorable, during acceptable and unfavorable years for growing.

\section{MATERIAL AND METHODS}

The work was developed in the years 2012 to 2018, in Augusto Pestana, RS, Brazil ( $28^{\circ} 26^{\prime} 30^{\prime \prime} \mathrm{S}$ latitude and $54^{\circ} 00^{\prime} 58^{\prime \prime}$ 'W longitude). The soil in the experimental area is classified as a typical Dystrophic Red Latosol (Oxisol). The climate of the region, according to Köppen's classification, is of the humid subtropical type. Before sowing, soil analysis was carried out and the following chemical characteristics were identified (Tedesco et al., 1995): i) soybean/wheat system $\left(\mathrm{pH}=6.1, \mathrm{P}=49.1 \mathrm{mg} \mathrm{dm}^{-3}, \mathrm{~K}=424 \mathrm{mg} \mathrm{dm}^{-3}, \mathrm{OM}=\right.$ $3.0 \%, \mathrm{Al}=0 \mathrm{cmol}_{\mathrm{c}} \mathrm{dm}^{-3}, \mathrm{Ca}=6.3 \mathrm{cmol}_{\mathrm{c}} \mathrm{dm}^{-3}$ and $\mathrm{Mg}=2.5 \mathrm{cmol}_{\mathrm{c}} \mathrm{dm}^{-3}$ ) and; ii) corn/wheat system $\left(\mathrm{pH}=6.5, \mathrm{P}=23.6 \mathrm{mg} \mathrm{dm}, \mathrm{K}=295 \mathrm{mg} \mathrm{dm}^{-3}, \mathrm{OM}=2.9 \%, \mathrm{Al}=0 \mathrm{cmol}_{\mathrm{c}} \mathrm{dm}^{-3}, \mathrm{Ca}\right.$ $=6.8 \mathrm{cmol}_{\mathrm{c}} \mathrm{dm}^{-3}$ and $\left.\mathrm{Mg}=3.1 \mathrm{cmol}_{\mathrm{c}} \mathrm{dm}^{-3}\right)$. The experimental plot consisted of 5 lines of 5 $\mathrm{m}$ in length and spacing between lines of $0.2 \mathrm{~m}$ to compose the experimental unit of $5 \mathrm{~m}^{2}$. At sowing, 30 and $20 \mathrm{~kg} \mathrm{ha}^{-1}$ of $\mathrm{P}_{2} \mathrm{O}_{5}$ and $\mathrm{K}_{2} \mathrm{O}$ were applied, respectively, based on the levels of $\mathrm{P}$ and $\mathrm{K}$ in the soil for expected grain yield of $3 \mathrm{tha}^{-1}$ and $\mathrm{N}$ at the sowing with 10 $\mathrm{kg} \mathrm{ha}^{-1}$, with the rest to cover the doses proposed in top dressing, with nitrogen made available in the form of urea. The seeds were submitted to a germination and vigor test in the laboratory, in order to correct the desired density of 400 viable seeds $\mathrm{m}^{-2}$. During the execution of the study, applications of tebuconazole fungicide were performed at a dosage of $0.75 \mathrm{~L} \mathrm{ha}^{-1}$. Weed control was carried out with metsulfuron-methyl herbicide at a dose of $4 \mathrm{~g} \mathrm{ha}^{-1}$. The cultivar used was TBIO Sintonia, widely accepted for its potential for yield and genetic resistance to the vast majority of leaf and ear diseases.

In each year and each growing system (soybean/wheat, corn/wheat system), two experiments were conducted, one to quantify the biomass yield (BY, $\mathrm{kg} \mathrm{ha}^{-1}$ ) by the cuts made every 30 days until physiological maturity and, the other, to estimate grain yield (GY, $\mathrm{kg} \mathrm{ha}^{-1}$ ). Therefore, in the four experiments, the design was randomized blocks with four replications in a 5 x 3 factorial scheme, for doses of $\mathrm{N}$-fertilizer $(0,30,60,90$ and $120 \mathrm{~kg}$ $\mathrm{ha}^{-1}$ ) and ways of supplying the nutrient [full condition (100\%) at the phenological stage $\mathrm{V}_{3}$ (third expanded leaf); fractionated $(70 \% / 30 \%)$ in the phenological stage $\mathrm{V}_{3} / \mathrm{V}_{6}$ (third and sixth expanded leaf) and fractionated $(70 \% / 30 \%)$ in the phenological stage $V_{3} / R_{1}$ (third expanded leaf and ear differentiation)], respectively, totaling 240 experimental units. These nitrogen application times and supply percentages are described in research results and in wheat cultivation recommendation manuals. In all the years of growing, the application of $\mathrm{N}$-fertilizer in a single and fractionated dose in stages $\mathrm{V}_{3}, \mathrm{~V}_{3} / \mathrm{V}_{6}$ and $\mathrm{V}_{3} / \mathrm{R}_{1}$, was at $30,30 / 60$ and 30/90 days after the emergence of wheat, respectively. The harvesting of the experiments to estimate the biomass and grain yield occurred manually by cutting the three central lines of each plot, a stage close to the harvest point (125 days), with grain moisture of $15 \%$. The moment of grain harvest was also defined as the last cut in the experiment aimed at analyzing biomass yield. The plots for grain harvesting were tracked with a 
stationary harvester and sent to the laboratory to correct grain moisture to $13 \%$, after weighing and estimating grain yield $\left(\mathrm{GY}, \mathrm{kg} \mathrm{ha}^{-1}\right)$. Samples for biomass analysis were sent to a forced air oven at a temperature of $65^{\circ} \mathrm{C}$, until reaching constant weight for weighing and estimation of biomass yield (BY, $\mathrm{kg} \mathrm{ha}^{-1}$ ).

The assumptions of homogeneity and normality of data were assessed via the Bartlett test, and analysis of variance was performed to detect the main and interaction effects. The linear function $\left(B Y=b_{0} \pm b_{i} x\right)$ was adjusted to estimate the biomass yield rate $\left(\mathrm{kg} \mathrm{day}^{-1} \mathrm{ha}^{-1}\right)$ with time as independent variable. Means were compared by Scott \& Knott in the analysis of grain yield, in each nitrogen supply dose and condition. Under conditions where there was significant quadratic response $\left(G Y=b_{0} \pm b_{1} x \pm b_{2} x^{2}\right)$ of grain yield to nitrogen applied levels, maximum technical efficiency $\left(M T E=-\left[\left(b_{1}\right) /\left(2 b_{2}\right)\right]\right)$ and maximum economic efficiency $\left(M E E=\left[(t / w)-b_{1}\right] /\left(2 b_{2}\right)\right)$ from nitrogen use to grain yield were estimated. For maximum economic efficiency, the price of the product (w) and the price of the input (t) are included in the model. The values used represent the average prices practiced in the northwest region of Rio Grande do Sul, with an input price (nitrogen) of US\$ 0.70 for each $\mathrm{kg}$ of nitrogen supplied and a price of US\$ 0.14 for each $\mathrm{kg}$ of wheat for sale. On the other hand, when there was significant linear behavior $\left(G Y=a \pm b_{i} x\right)$, grain yield estimate was obtained through the technical recommendation of nitrogen, following the succession crop for the $3 \mathrm{t} \mathrm{ha}^{-1}$. In the determinations, the computer program Genes was used (Cruz, 2006).

\section{RESULTS AND DISCUSSION}

Table 1 and Figure 1 present information on temperature, rainfall, and yield of wheat grains. The year 2013 was marked by adequate conditions of minimum, average, and maximum temperature during the wheat development cycle, favoring the production of tillers and the distribution of photoassimilates to yield. The occurrence of rainfall in the days preceding the supply of $\mathrm{N}$-fertilizer, in the phenological stages $\mathrm{V}_{3}, \mathrm{~V}_{6}$ and $\mathrm{R}_{1}$, implied in soil moisture favorable to the management of the nutrient (Figure 1). The total rainfall was below the historical average of the last 25 years, but with an adequate distribution throughout the cycle (Figure 1). In 2016 (Table 1), there was a uniform distribution of rainfall during wheat growing, however, below the historical average. At the time of Nfertilizer, $V_{3}, V_{6}$ and $R_{1}$, there was adequate soil moisture due to rains that occurred in previous days, favoring the use of the nutrient by the plant. In 2016 temperatures were milder, reducing possible nitrogen losses through volatilization (Figure 1). Therefore, the minimum, maximum and average temperatures in 2016 were reduced and stable throughout the cycle. In 2018 (Table 1), the minimum, average and maximum temperatures were adequate during the wheat development cycle. In the previous moments of nitrogen fertilizations in the phenological stages $\mathrm{V}_{3}, \mathrm{~V}_{6}$ and $\mathrm{R}_{1}$, the soil presented adequate humidity for the management of the nutrient, without the occurrence of more intense rains, avoiding losses by leaching. In addition, an adequate distribution of rainfall was observed throughout the cycle, but below the historical average (Table 1). The distribution of rainfall with mild temperatures during the cycles of 2013, 2016 and 2018 promoted an average grain yield higher than the desired expectation of $3000 \mathrm{~kg} \mathrm{ha}^{-1}$, characterizing as favorable years (FY) for wheat growing (Figure 1, Table 1). 
Table 1. Temperature and rainfall during the months of growing and average yield of wheat grains.

\begin{tabular}{|c|c|c|c|c|c|c|c|c|c|}
\hline \multirow{2}{*}{ Year } & \multirow{2}{*}{ Month } & \multicolumn{3}{|c|}{ Temperature $\left({ }^{\circ} \mathrm{C}\right)$} & \multicolumn{2}{|l|}{ Rainfall (mm) } & \multirow{2}{*}{$\begin{array}{c}\mathrm{GY}_{\overline{\mathrm{XS}}} \\
\left(\mathrm{kg} \mathrm{ha}^{-1}\right)\end{array}$} & \multirow{2}{*}{$\underset{\left(\mathrm{kg} \mathrm{ha}^{-1}\right)}{\mathrm{GY}_{\overline{\bar{X}} \mathrm{M}}}$} & \multirow{2}{*}{ Class } \\
\hline & & Min & $\operatorname{Max}$ & Ave & Average of 25 years $*$ & Occurred & & & \\
\hline \multirow{7}{*}{2012} & May & 10.4 & 26.6 & 18.5 & 149 & 18 & \multirow{7}{*}{$2341 \mathrm{~b}$} & \multirow{7}{*}{$2046 \mathrm{~b}$} & \multirow{7}{*}{ AY } \\
\hline & June & 8.8 & 22.0 & 15.4 & 163 & 57 & & & \\
\hline & July & 6.4 & 19.7 & 13.0 & 135 & 181 & & & \\
\hline & August & 12.9 & 23.4 & 18.1 & 138 & 61 & & & \\
\hline & September & 12.0 & 23.0 & 17.5 & 167 & 195 & & & \\
\hline & October & 15.0 & 25.5 & 20.2 & 156 & 287 & & & \\
\hline & Total & - & - & - & 908 & 799 & & & \\
\hline \multirow{7}{*}{2013} & May & 10.0 & 22.6 & 16.3 & 149 & 108 & \multirow{7}{*}{$3447 \mathrm{a}$} & \multirow{7}{*}{$2737 \mathrm{a}$} & \multirow{7}{*}{ FY } \\
\hline & June & 8.9 & 20.0 & 14.5 & 163 & 74 & & & \\
\hline & July & 7.0 & 20.6 & 13.8 & 135 & 103 & & & \\
\hline & August & 6.6 & 19.8 & 13.2 & 138 & 169 & & & \\
\hline & September & 9.6 & 21.0 & 15.3 & 167 & 123 & & & \\
\hline & October & 13.2 & 27.1 & 20.2 & 156 & 144 & & & \\
\hline & Total & - & - & - & 908 & 721 & & & \\
\hline \multirow{7}{*}{2014} & May & 10.8 & 23.6 & 17.2 & 149 & 382 & \multirow{7}{*}{$1475 \mathrm{c}$} & \multirow{7}{*}{$1201 \mathrm{c}$} & \multirow{7}{*}{ UY } \\
\hline & June & 9.2 & 20.7 & 16.1 & 163 & 412 & & & \\
\hline & July & 9.7 & 21.8 & 15.7 & 135 & 144 & & & \\
\hline & August & 8.8 & 23.7 & 16.2 & 138 & 78 & & & \\
\hline & September & 13.3 & 23.5 & 18.4 & 167 & 275 & & & \\
\hline & October & 16.0 & 27.7 & 21.8 & 156 & 231 & & & \\
\hline & Total & - & - & - & 908 & 1522 & & & \\
\hline & May & 13.1 & 22.7 & 17.9 & 149 & 181 & & & \\
\hline & June & 9.7 & 21.1 & 15.4 & 163 & 228 & & & \\
\hline & July & 10.2 & 18.7 & 14.4 & 135 & 212 & & & \\
\hline 2015 & August & 13.4 & 24.6 & 19.0 & 138 & 87 & $2455 \mathrm{~b}$ & $1972 \mathrm{~b}$ & AY \\
\hline & September & 12.4 & 19.6 & 16.0 & 167 & 127 & & & \\
\hline & October & 16.1 & 24.8 & 20.4 & 156 & 162 & & & \\
\hline & Total & - & - & - & 908 & 997 & & & \\
\hline & May & 11.1 & 20.9 & 16.0 & 149 & 56 & & & \\
\hline & June & 4.7 & 19.3 & 12.0 & 163 & 10 & & & \\
\hline & July & 8.2 & 21.2 & 14.7 & 135 & 81 & & & \\
\hline 2016 & August & 9.4 & 22.5 & 15.9 & 138 & 160 & $3210 \mathrm{a}$ & $2619 \mathrm{a}$ & FY \\
\hline & September & 8.4 & 23.8 & 16.1 & 167 & 56 & & & \\
\hline & October & 13.2 & 26.8 & 20.0 & 156 & 326 & & & \\
\hline & Total & - & - & - & 908 & 689 & & & \\
\hline & May & 14 & 33.8 & 18.4 & 149 & 434 & & & \\
\hline & June & 10.7 & 21.8 & 16.2 & 163 & 146 & & & \\
\hline & July & 8.3 & 24.4 & 16.4 & 135 & 11 & & & \\
\hline 2017 & August & 11.4 & 23.7 & 17.6 & 138 & 118 & $1749 \mathrm{c}$ & $1121 \mathrm{c}$ & UY \\
\hline & September & 15.36 & 27.1 & 21.2 & 167 & 162 & & & \\
\hline & October & 14.1 & 26.8 & 20.5 & 156 & 304 & & & \\
\hline & Total & - & - & - & 908 & 1175 & & & \\
\hline & May & 13.2 & 25.8 & 19.5 & 149 & 63 & & & \\
\hline & June & 7.4 & 19.4 & 13.4 & 163 & 104 & & & \\
\hline & July & 9.2 & 20.1 & 14.6 & 135 & 80 & & & \\
\hline 2018 & August & 6.2 & 20.0 & 13.1 & 138 & 120 & $3083 \mathrm{a}$ & 2431 a & FY \\
\hline & September & 13.1 & 24.8 & 18.9 & 167 & 184 & & & \\
\hline & October & 15.6 & 25.3 & 20.4 & 156 & 243 & & & \\
\hline & Total & - & - & - & 908 & 794 & & & \\
\hline
\end{tabular}

Min = minimum; $\mathrm{Max}=$ maximum; $\mathrm{Av}=$ average $; \mathrm{GY}_{\overline{\mathrm{X}} \mathrm{S}}=$ average grain yield of the soybean/wheat system; $\mathrm{GY}_{\overline{\mathrm{X}} \mathrm{M}}=$ average grain yield of the corn/wheat system; * = Average rainfall obtained from May to October 1993 to 2018; Averages followed by the same letter in the column do not differ in the probability of $5 \%$ error by the Scott \& Knott test; AY = Acceptable year; FY = Favorable year; UY = Unfavorable year. 
In 2012, expressive values of maximum average temperature were registered (Table 1), a condition that reduces photosynthesis efficiency with a significant increase in the respiration rate, causing losses in grain yield. During the cycle, the rains were restrictive, especially in the moments before the supply of the nutrient, which favors nitrogen losses through volatilization. Although a more restrictive condition, soil moisture for fertilization in $V_{3}, V_{6}$ and $R_{1}$ was adequate due to rains from previous days. However, the volume of rainfall was below the historical average (Table 1), with an inadequate rainfall distribution throughout the development cycle of the wheat crop. In 2015 (Figure 1), the maximum temperatures at the beginning of wheat development were high. This condition favored faster elongation with reduced production of new tillers, a component directly linked to grain yield. The high temperatures and a lack of rainfall promoted reduced soil moisture at the time of nitrogen fertilization at stages $\mathrm{V}_{3}, \mathrm{~V}_{6}$ and $\mathrm{R}_{1}$, favoring the losses of the nutrient through volatilization (Figure 1). The accumulated rainfall was close to the average observed in 25 years. The meteorological information together with the yield obtained in the years 2012 and 2015, with an expectation of over $2000 \mathrm{~kg} \mathrm{ha}^{-1}$, characterize the years in acceptable (AY) to the yield of wheat grains (Figure 1, Table 1).

In 2014, there were high temperatures followed by excessive rainfall at the beginning of the crop development cycle (Figure 1), a condition also observed close to the grain harvest. The volume of rainfall was higher than the historical average (Table 1) with irregular distribution throughout the cycle. These facts justify the low yield, either due to the loss of the nutrient by leaching in the stages of supply of the nutrient in $V_{3}, V_{6}$ and $R_{1}$ and the losses caused by the excess of rain during maturation. In 2017, the volume of rainfall was higher than the historical average (Table 1) with inadequate distribution throughout the cycle (Figure 1). Minimum, average and maximum temperatures during the wheat development cycle were higher and unstable compared to other years. The supply of the nutrient in the phenological stages $V_{3}$ and $R_{1}$ was of low soil moisture due long period without rainfall, with the exception of fertilization carried out in the stage $\mathrm{V}_{6}$. The high temperatures of the years 2014 and 2017, together with the expressive rainfall, promoted an average grain yield above $1000 \mathrm{~kg} \mathrm{ha}^{-1}$, much lower than the desired expectation of $3000 \mathrm{~kg}$ $\mathrm{ha}^{-1}$, justifying the classification of unfavorable years (UY) for wheat growing (Figure 1, Table 1).

In modern agriculture, the need to produce more and more food, minimize operating costs, reduce soil movement and predict weather conditions, are important issues for greater wheat yield (Caron et al., 2017; Vasconcellos et al., 2018). The climatic challenges for agricultural production show the need for current and future efforts in the search for strategies to guarantee the increase of the productive potential (Araus et al., 2008; Arenhardt et al., 2015). Wheat growing in the southern region of Brazil gives inconsistent yields, since f frosts, intense rains, hail and water stress has resulted in great yield vulnerability (Luche et al., 2015; Mamann et al., 2017a).

The efficiency of the application of urea, the main source of nitrogen fertilization, depends on favorable weather conditions, mainly an adequate rainfall distribution and milder temperatures (Arenhardt et al., 2015; Trautmann et al., 2020). Cordeiro et al. (2015) state that wheat requires regions with milder temperatures and adequate distribution and intensity of rainfall during the growing cycle. Excessive rainfall after fertilization causes damage to the plant due to lack of oxygen, in addition to the loss of nutrient by nitrate leaching, impacting on high environmental pollution (Ercoli et al., 2013; Mandal et al., 
2016). Therefore, the favorable climate for wheat is described as that of milder temperatures and high solar radiation, without rain large volumes, with adequate distribution for maintaining stored soil moisture (Guarienti et al., 2004; Silva et al., 2016). Excess heat, in addition to inducing quantitative and qualitative losses in production, shortens the cycle length, reduces leaf area, plant height and percentage of flower fertilization, accelerating the filling period and decreasing the average weight of the grains (Ribeiro et al., 2012; Mamann et al., 2020). Therefore, the guarantee of food security with quantity and quality of grains is dependent on the weather conditions of wheat growing (Shewry, 2007; Pennacchi et al., 2018).

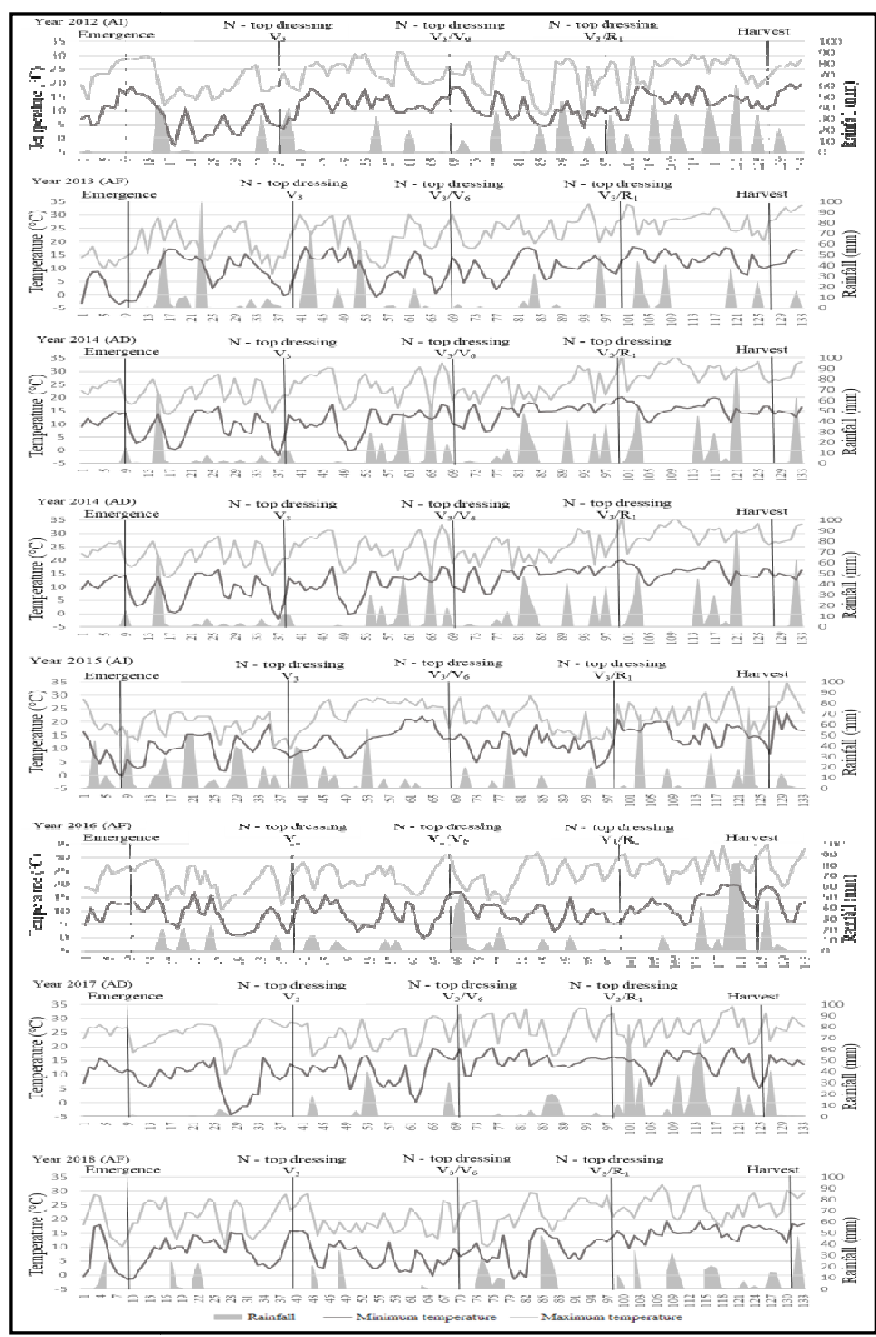

Figure 1. Rainfall and maximum and minimum temperature in the wheat growing cycle and the timing of nitrogen supply. $\mathrm{V}_{3}=$ Full condition $(100 \%)$ of the nitrogen dose in the third expanded leaf. $\mathrm{V}_{3} / \mathrm{V}_{6}=$ Fractionated condition $(70 \% / 30 \%)$ of the nitrogen dose in the third and sixth expanded leaf and $V_{3} / R_{1}=$ Fractionated condition $(70 \% / 30 \%)$ of the nitrogen dose in the third expanded leaf and ear differentiation; AY = Acceptable year; FY $=$ Favorable year; UY = Unfavorable year. 
In the soybean/wheat system (Table 2), by the linear coefficient of the model, the highest rate of biomass yield was obtained with the highest dose of the nutrient, either in full or fractional doses, regardless of the condition of the agricultural year.

Table 2. Biomass yield rate as a function of time $\left(\mathrm{kg} \mathrm{day}^{-1} \mathrm{ha}^{-1}\right)$ and grain yield averages $\left(\mathrm{kg} \mathrm{ha}^{-1}\right)$ in wheat by dose and nitrogen fractionation in the soybean/wheat system.

\begin{tabular}{|c|c|c|c|c|c|c|c|c|c|}
\hline \multirow{2}{*}{$\begin{array}{l}\text { Dose } \\
\mathrm{N}\end{array}$} & \multicolumn{3}{|l|}{$\mathrm{V}_{3}$} & \multicolumn{3}{|l|}{$\mathrm{V}_{3} / \mathrm{V}_{6}$} & \multicolumn{3}{|l|}{$\mathrm{V}_{3} / \mathrm{R}_{1}$} \\
\hline & $B Y=a+b x$ & $\mathrm{R}^{2}$ & $\overline{\mathrm{X}}_{\mathrm{GY}}$ & $\mathrm{BY}=\mathrm{a}+\mathrm{bx}$ & $\mathrm{R}^{2}$ & $\overline{\mathrm{X}}_{\mathrm{GY}}$ & $\mathrm{BY}=\mathrm{a}+\mathrm{bx}$ & $\mathrm{R}^{2}$ & $\overline{\mathrm{X}}_{\mathrm{GY}}$ \\
\hline \multicolumn{10}{|c|}{$2012(\mathrm{AY})$} \\
\hline 0 & $1633+68.9 x^{*}$ & 87 & $1712 \mathrm{c}$ & $1259+62.0 x^{*}$ & 93 & $1608 \mathrm{~d}$ & $1292+58.1 \mathrm{x}^{*}$ & 97 & $1574 \mathrm{~d}$ \\
\hline 30 & $1697+73.5 x^{*}$ & 90 & $2138 \mathrm{~b}$ & $1398+69.4 x^{*}$ & 90 & $2116 \mathrm{c}$ & $1877+67.9 x^{*}$ & 96 & $2048 \mathrm{c}$ \\
\hline 60 & $1840+75.9 \mathrm{x}^{*}$ & 87 & $2330 \mathrm{~b}$ & $1645+79.6 x^{*}$ & 84 & $2371 \mathrm{~b}$ & $2026+80.4 x^{*}$ & 89 & 2486 b \\
\hline 90 & $2143+84.1 x^{*}$ & 90 & $2673 \mathrm{a}$ & $1992+88.6 x^{*}$ & 90 & $2713 \mathrm{a}$ & $2195+86.2 x^{*}$ & 85 & $2724 \mathrm{a}$ \\
\hline 120 & $2414+94.6 x^{*}$ & 90 & $2875 \mathrm{a}$ & $1974+89.8 x^{*}$ & 90 & $2901 \mathrm{a}$ & $2634+96.0 x^{*}$ & 90 & $2847 \mathrm{a}$ \\
\hline General & $1945+79.4 x^{*}$ & 90 & $2346 \mathrm{~A}$ & $1654+77.9 x^{*}$ & 87 & $2342 \mathrm{~A}$ & $2005+77.7 x^{*}$ & 91 & $2336 \mathrm{~A}$ \\
\hline \multicolumn{10}{|l|}{2013 (FY) } \\
\hline 0 & $1975+64.8 x^{*}$ & 98 & $2069 \mathrm{e}$ & $2478+70.8 x^{*}$ & 94 & $1920 \mathrm{e}$ & $2067+61.7 x^{*}$ & 90 & $1854 \mathrm{e}$ \\
\hline 30 & $2075+785 x^{*}$ & 99 & $2860 \mathrm{~d}$ & $2806+81.9 x^{*}$ & 96 & $2915 \mathrm{~d}$ & $2636+71.9 x^{*}$ & 90 & $2563 \mathrm{~d}$ \\
\hline 60 & $2697+100.0 x^{*}$ & 97 & $3953 \mathrm{c}$ & $2629+93.9 x^{*}$ & 96 & $3591 \mathrm{c}$ & $2145+78.1 \mathrm{x}^{*}$ & 96 & $3449 \mathrm{c}$ \\
\hline 90 & $2536+102.5 x^{*}$ & 97 & $4307 \mathrm{~b}$ & $2981+106.8 x^{*}$ & 95 & $4288 \mathrm{~b}$ & $2181+82.1 x^{*}$ & 99 & $4041 \mathrm{~b}$ \\
\hline 120 & $2396+105.5 x^{*}$ & 96 & $4935 \mathrm{a}$ & $3300+119.0 x^{*}$ & 93 & $4676 \mathrm{a}$ & $3058+102.9 \mathrm{x}^{*}$ & 98 & $4288 \mathrm{a}$ \\
\hline General & $2336+90.3 x^{*}$ & 91 & $3625 \mathrm{~A}$ & $2839+94.5 x^{*}$ & 90 & $3478 \mathrm{~A}$ & $2417+79.3 x^{*}$ & 91 & $3239 \mathrm{~B}$ \\
\hline \multicolumn{10}{|l|}{2014 (UY) } \\
\hline 0 & $449+45.1 \mathrm{x}^{*}$ & 93 & $1195 \mathrm{~b}$ & $263+40.2 x^{*}$ & 89 & $942 \mathrm{c}$ & $547+42.9 x^{*}$ & 93 & $998 \mathrm{c}$ \\
\hline 30 & $826+55.5 x^{*}$ & 95 & $1346 \mathrm{~b}$ & $586+54.4 x^{*}$ & 94 & $1403 \mathrm{~b}$ & $1287+59.4 x^{*}$ & 98 & $1326 \mathrm{~b}$ \\
\hline 60 & $1168+64.3 x^{*}$ & 97 & $1798 \mathrm{a}$ & $1160+66.4 x^{*}$ & 97 & $1656 \mathrm{a}$ & $1005+62.2 x^{*}$ & 98 & $1549 \mathrm{a}$ \\
\hline 90 & $1024+67.0 x *$ & 96 & $1736 \mathrm{a}$ & $1057+68.1 x^{*}$ & 97 & $1735 \mathrm{a}$ & $1180+67.7 x^{*}$ & 98 & $1658 \mathrm{a}$ \\
\hline 120 & $1021+72.4 x^{*}$ & 95 & $1613 \mathrm{a}$ & $1001+73.8 x^{*}$ & 96 & $1536 \mathrm{~b}$ & $883+72.1 x^{*}$ & 94 & $1640 \mathrm{a}$ \\
\hline General & $898+60.8 x^{*}$ & 92 & $1538 \mathrm{~A}$ & $813+60.6 x^{*}$ & 89 & $1454 \mathrm{~A}$ & $980+60.8 \mathrm{x}^{*}$ & 90 & $1434 \mathrm{~A}$ \\
\hline \multicolumn{10}{|c|}{$2015(\mathrm{AY})$} \\
\hline 0 & $1138+59.2 x^{*}$ & 97 & $1608 \mathrm{c}$ & $1136+56.7 x^{*}$ & 96 & $1431 \mathrm{~d}$ & $1106+56.5 x^{*}$ & 95 & $1436 \mathrm{e}$ \\
\hline 30 & $1221+63.7 x^{*}$ & 96 & $2103 \mathrm{~b}$ & $1344+68.7 x^{*}$ & 97 & $2163 \mathrm{c}$ & $1506+66.8 x^{*}$ & 96 & $2070 \mathrm{~d}$ \\
\hline 60 & $1773+79.5 x^{*}$ & 98 & $2875 \mathrm{a}$ & $1621+78.8 x^{*}$ & 97 & $2579 \mathrm{~b}$ & $1512+74.5 x^{*}$ & 96 & $2499 \mathrm{c}$ \\
\hline 90 & $1824+85.8 x^{*}$ & 95 & $3027 \mathrm{a}$ & $1876+88.7 x^{*}$ & 96 & $2966 \mathrm{a}$ & $1361+77.1 x^{*}$ & 94 & $2850 \mathrm{~b}$ \\
\hline 120 & $1857+90.3 x^{*}$ & 97 & $3057 \mathrm{a}$ & $1859+91.0 x^{*}$ & 96 & $3106 \mathrm{a}$ & $1657+87.5 x^{*}$ & 92 & $3052 \mathrm{a}$ \\
\hline General & $1562+75.7 x^{*}$ & 95 & $2534 \mathrm{~A}$ & $1567+76.7 x^{*}$ & 93 & $2449 \mathrm{~A}$ & $1429+72.5 x^{*}$ & 90 & $2381 \mathrm{~A}$ \\
\hline \multicolumn{10}{|l|}{2016 (FY) } \\
\hline 0 & $2221+83.9 x^{*}$ & 94 & $2581 \mathrm{~b}$ & $2217+82.0 \mathrm{x}^{*}$ & 96 & $2591 \mathrm{c}$ & $2285+81.3 x^{*}$ & 98 & $2453 c$ \\
\hline 30 & $2563+92.6 x^{*}$ & 98 & $3232 \mathrm{a}$ & $2431+93.4 x^{*}$ & 98 & $3177 \mathrm{~b}$ & $2651+95.3 x^{*}$ & 95 & $2999 \mathrm{~b}$ \\
\hline 60 & $3144+113.9 x^{*}$ & 92 & $3598 \mathrm{a}$ & $2865+106.9 x^{*}$ & 96 & $3400 \mathrm{a}$ & $2551+99.1 x^{*}$ & 95 & $3192 \mathrm{~b}$ \\
\hline 90 & $3582+121.5 x^{*}$ & 98 & $3565 \mathrm{a}$ & $3269+115.3 x^{*}$ & 98 & $3387 \mathrm{a}$ & $2967+112.5 x^{*}$ & 96 & $3519 a$ \\
\hline 120 & $3157+120.9 x^{*}$ & 96 & $3511 \mathrm{a}$ & $3377+124.2 x^{*}$ & 96 & $3495 \mathrm{a}$ & $3464+116.6 x^{*}$ & 98 & $3443 \mathrm{a}$ \\
\hline General & $2933+106.6 x^{*}$ & 96 & $3297 \mathrm{~A}$ & $2831+104.3 x^{*}$ & 97 & $3210 \mathrm{~A}$ & $2783+100.9 x^{*}$ & 98 & $3121 \mathrm{~A}$ \\
\hline \multicolumn{10}{|c|}{2017 (UY) } \\
\hline 0 & $1524+53.2 x^{*}$ & 92 & $1383 \mathrm{c}$ & $1446+53.4 x^{*}$ & 95 & $1426 \mathrm{c}$ & $1669+56.1 x^{*}$ & 95 & $1344 \mathrm{~b}$ \\
\hline 30 & $1980+65.3 x^{*}$ & 93 & $1677 \mathrm{~b}$ & $2025+74.6 x^{*}$ & 93 & $1871 \mathrm{~b}$ & $1636+58.8 x^{*}$ & 91 & $1408 \mathrm{~b}$ \\
\hline 60 & $2273+78.5 x^{*}$ & 94 & $1967 \mathrm{a}$ & $2085+79.8 x^{*}$ & 92 & $2075 \mathrm{a}$ & $1899+70.2 x^{*}$ & 94 & $1693 \mathrm{a}$ \\
\hline 90 & $2455+84.9 x^{*}$ & 94 & $1963 \mathrm{a}$ & $2350+82.0 x^{*}$ & 91 & $2032 \mathrm{a}$ & $2159+74.5 x^{*}$ & 93 & $1704 \mathrm{a}$ \\
\hline 120 & $2913+90.6 x^{*}$ & 94 & $1897 \mathrm{a}$ & $2901+91.9 x^{*}$ & 94 & $2028 \mathrm{a}$ & $2337+83.1 x^{*}$ & 93 & $1664 \mathrm{a}$ \\
\hline General & $2229+74.5 x^{*}$ & 90 & $1777 \mathrm{~A}$ & $2161+76.3 x^{*}$ & 91 & $1887 \mathrm{~A}$ & $1940+68.5 x^{*}$ & 92 & $1563 \mathrm{~B}$ \\
\hline \multicolumn{10}{|c|}{$2018(\mathrm{FY})$} \\
\hline 0 & $1640+82.6 x^{*}$ & 92 & $2243 c$ & $2217+82.9 x^{*}$ & 97 & $2547 \mathrm{~b}$ & $1925+79.8 x^{*}$ & 99 & $2456 \mathrm{c}$ \\
\hline 30 & $2113+99.8 x^{*}$ & 95 & $2823 \mathrm{~b}$ & $2076+97.2 x^{*}$ & 97 & $2718 \mathrm{~b}$ & $2044+92.3 x^{*}$ & 98 & $2703 \mathrm{~b}$ \\
\hline 60 & $3513+116.6 x^{*}$ & 99 & $3303 \mathrm{a}$ & $3116+122.6 x^{*}$ & 99 & $3537 \mathrm{a}$ & $3047+93.0 x^{*}$ & 96 & $3315 \mathrm{a}$ \\
\hline 90 & $3765+129.1 x^{*}$ & 99 & $3345 \mathrm{a}$ & $3838+137.1 x^{*}$ & 98 & $3580 \mathrm{a}$ & $2988+117.2 x^{*}$ & 99 & $3369 \mathrm{a}$ \\
\hline 120 & $3463+128.6 x^{*}$ & 99 & $3352 \mathrm{a}$ & $3743+136.9 x^{*}$ & 99 & $3701 \mathrm{a}$ & $2922+121.9 x^{*}$ & 97 & $3256 \mathrm{a}$ \\
\hline General & $2899+111.3 x^{*}$ & 98 & $3013 \mathrm{~A}$ & $2998+115.3 x^{*}$ & 94 & $3217 \mathrm{~A}$ & $2810+106.5 x^{*}$ & 97 & $3020 \mathrm{~A}$ \\
\hline
\end{tabular}


It is noteworthy that the increase in the biomass rate was not accompanied by the increase in grain yield by nitrogen doses, regardless of the supply condition, single or fractioned. A condition that indicates a trend of linearity of biomass yield and of trend quadratic of grain yield. Therefore, in Table 2, in an unfavorable year (2014 and 2017) of growing, greater yield is evidenced with the use of the dose of $60 \mathrm{~kg} \mathrm{ha}^{-1}$ of nitrogen, not differing from the points of 90 and $120 \mathrm{~kg} \mathrm{ha}^{-1}$ of nitrogen, regardless of the form of supply. In the favorable condition of 2013, there was a tendency to increase yield with an increase in nitrogen dose. However, in the favorable year of 2016, high yield is obtained with the dose of $60 \mathrm{~kg} \mathrm{ha}^{-1}$, similar to the higher doses, regardless of the form of supply. Although they are favorable years, the complexity of the nutrient dynamics shows different utilization behaviors. The year 2016 stands out, with adequate conditions of rainfall and milder and more stable temperatures along the cycle increased the efficiency of the nutrient use. In the years of acceptable growing, similar results were observed, with the biomass yield increased with the nutrient dose and the maximum grain yield from the points of 60 or $90 \mathrm{~kg} \mathrm{ha}^{-1}$, regardless of the form of supply. In general, regardless of the nutrient dose, the biomass rates were similar in the condition of supply in full dose and in the fractionation in $V_{3} / \mathrm{V}_{6}$ and with reduction of the biomass yield in fractionation $V_{3} / R_{1}$. This same trend was observed in the analysis of grain yield averages.

In Table 3, of the corn/wheat system, also the highest biomass yield rates were obtained at the highest dose of the nutrient. However, in the different conditions of the agricultural year, the dose of $90 \mathrm{~kg} \mathrm{ha}^{-1}$ of nitrogen indicated the point with the highest value of grain yield, similar the dose of $120 \mathrm{~kg} \mathrm{ha}^{-1}$. In this system, it is noted a dependence expected by the greater use of $\mathrm{N}$-fertilizer, the system does not involve nitrogen input by nitrogen fixing bacteria and the greater difficulty of high carbon/nitrogen ratio straw decomposing. In this condition, the use of fractionation in $V_{3} / R_{1}$ was even more inefficient in expressing grain yield, however, when supplied in full and fractionated doses in $V_{3} / V_{6}$, it showed similar results. The results already indicate the need for lower doses of nitrogen, as they do not follow the expected yield due to the nitrogen dose according to the fertilization manuals. In addition, the wheat growing on the soybean residue contributes significantly to reduce the dependence on $\mathrm{N}$-fertilizer in the system, seeking satisfactory yield.

Nitrogen plays a fundamental role in the growth and development of wheat plants, with direct effects on the biomass and grain yields (Stefen et al., 2015; Mamann et al., 2017b). The favoring of the growing year is decisive over yield potentials, due to the volume and rainfall distribution, temperature and solar radiation (Benin et al., 2012; Nörnberg et al., 2015). Heinemann et al. (2006) observed that nitrogen deficiency reduces the capture of solar radiation by wheat with direct effects on the rate of biomass and grains. The biochemical composition of plant residues also affects the dose and timing of supply of $\mathrm{N}$-fertilizer in view of the release rate of the nutrient in the soil and decomposing tissues (Siqueira Neto et al., 2010; Silva et al., 2015). Mantai et al. (2015) observed in oats, growth in the biomass rate with the increase of doses of $\mathrm{N}$-fertilizer in a single dose in the growing systems, a condition not always accompanied by the higher grain yield, results also verified in this research. In wheat, Liang et al. (2019) found that the increase in nitrogen concentration in plant tissue significantly increased the biomass rate by applying the nutrient in a single dose. Research has indicated that the fractional supply of nitrogen can further decrease nutrient losses at the most propitious times for fertilization, improving the efficiency of the nutrient (Benin et al, 2012; Ferrari et al., 2016). 
Table 3. Biomass yield rate and grain yield averages in wheat by dose and nitrogen fractionation in the corn/wheat system.

\begin{tabular}{|c|c|c|c|c|c|c|c|c|c|}
\hline \multirow{2}{*}{$\begin{array}{c}\text { Dose } \\
\mathrm{N}\end{array}$} & \multicolumn{3}{|c|}{$\mathrm{V}_{3}$} & \multicolumn{3}{|c|}{$\mathrm{V}_{3} / \mathrm{V}_{6}$} & \multicolumn{3}{|c|}{$\mathrm{V}_{3} / \mathrm{R}_{1}$} \\
\hline & $\mathrm{BY}=\mathrm{a}+\mathrm{bx}$ & $\mathrm{R}^{2}$ & $\overline{\mathrm{X}}_{\mathrm{GY}}$ & $\mathrm{BY}=\mathrm{a}+\mathrm{bx}$ & $\mathrm{R}^{2}$ & $\overline{\mathrm{X}}_{\mathrm{GY}}$ & $\mathrm{BY}=\mathrm{a}+\mathrm{bx}$ & $\mathrm{R}^{2}$ & $\overline{\mathrm{X}}_{\mathrm{GY}}$ \\
\hline & & & & 2012 (AY) & & & & & \\
\hline 0 & $848+44.5 x^{*}$ & 92 & $867 \mathrm{~d}$ & $1222+45.7 x^{*}$ & 86 & $946 \mathrm{~d}$ & $1203+42.9 x^{*}$ & 93 & $943 \mathrm{~d}$ \\
\hline 30 & $1771+67.8 x^{*}$ & 90 & $1945 \mathrm{c}$ & $2273+75.2 x^{*}$ & 89 & $1913 \mathrm{c}$ & $1842+66.0 x^{*}$ & 92 & $1764 \mathrm{c}$ \\
\hline 60 & $2627+88.9 x^{*}$ & 90 & $2312 b$ & $2543+88.5 x^{*}$ & 90 & $2357 \mathrm{~b}$ & $2244+80.5 x^{*}$ & 91 & $2098 \mathrm{~b}$ \\
\hline 90 & $2729+93.7 x^{*}$ & 90 & $2638 \mathrm{a}$ & $2745+93.4 x^{*}$ & 91 & $2651 \mathrm{a}$ & $2483+87.0 x^{*}$ & 90 & $2386 \mathrm{a}$ \\
\hline 120 & $2953+99.5 x^{*}$ & 93 & $2693 \mathrm{a}$ & $3045+101.3 x^{*}$ & 90 & $2782 a$ & $2780+94.7 x^{*}$ & 90 & $2490 \mathrm{a}$ \\
\hline General & $2186+78.8 x^{*}$ & 89 & $2091 \mathrm{~A}$ & $2366+80.8 x^{*}$ & 85 & $2130 \mathrm{~A}$ & $2110+74.2 x^{*}$ & 90 & $1936 \mathrm{~A}$ \\
\hline & & & & $2013(\mathrm{FY})$ & & & & & \\
\hline 0 & $2067+58.9 x^{*}$ & 95 & $1268 \mathrm{~d}$ & $1958+57.8 x^{*}$ & 94 & $1376 \mathrm{e}$ & $1865+52.5 x^{*}$ & 93 & $1243 \mathrm{~d}$ \\
\hline 30 & $2758+80.7 x^{*}$ & 97 & $2500 \mathrm{c}$ & $3156+88.6 x^{*}$ & 94 & $2265 \mathrm{~d}$ & $2998+83.4 x^{*}$ & 93 & $2244 \mathrm{c}$ \\
\hline 60 & $3187+91.1 \mathrm{x}^{*}$ & 96 & $3083 \mathrm{~b}$ & $3236+93.0 x^{*}$ & 94 & $3077 \mathrm{c}$ & $3148+86.2 x^{*}$ & 94 & $2444 \mathrm{c}$ \\
\hline 90 & $3393+100.0 x^{*}$ & 97 & $3789 \mathrm{a}$ & $3274+101.0 x^{*}$ & 94 & $3669 \mathrm{~b}$ & $3172+93.2 x^{*}$ & 96 & $3021 \mathrm{~b}$ \\
\hline 120 & $3521+108.3 \mathrm{x}^{*}$ & 94 & $3871 \mathrm{a}$ & $3387+109.7 x^{*}$ & 95 & $3939 a$ & $3335+102.2 x^{*}$ & 95 & $3358 \mathrm{a}$ \\
\hline General & $2985+87.7 x^{*}$ & 91 & $2902 \mathrm{~A}$ & $3002+90.0 x^{*}$ & 90 & $2865 \mathrm{~A}$ & $2903+83.4 x^{*}$ & 93 & $2462 \mathrm{~B}$ \\
\hline & & & & 2014 (UY) & & & & & \\
\hline 0 & $778+36.1 x^{*}$ & 93 & $792 \mathrm{c}$ & $115+27.5 x^{*}$ & 83 & $607 \mathrm{c}$ & $862+32.7 x^{*}$ & 90 & $641 \mathrm{~d}$ \\
\hline 30 & $864+50.8 x^{*}$ & 91 & $1222 \mathrm{~b}$ & $733+40.8 x^{*}$ & 94 & $1027 \mathrm{~b}$ & $722+37.0 x^{*}$ & 93 & $1045 \mathrm{c}$ \\
\hline 60 & $641+55.9 x^{*}$ & 89 & $1344 \mathrm{~b}$ & $1187+58.6 x^{*}$ & 91 & $1476 \mathrm{a}$ & $869+42.6 x^{*}$ & 90 & $1232 \mathrm{~b}$ \\
\hline 90 & $866+60.9 x^{*}$ & 91 & $1489 \mathrm{a}$ & $1101+57.5 x^{*}$ & 91 & $1484 \mathrm{a}$ & $955+49.2 x^{*}$ & 93 & $1417 \mathrm{a}$ \\
\hline 120 & $1004+61.3 x^{*}$ & 94 & $1532 \mathrm{a}$ & $1184+59.7 x^{*}$ & 94 & $1554 \mathrm{a}$ & $1215+59.6 x^{*}$ & 93 & $1457 \mathrm{a}$ \\
\hline General & $830+53.0 x^{*}$ & 89 & $1276 \mathrm{~A}$ & $864+48.8 x^{*}$ & 88 & $1230 \mathrm{~A}$ & $924+44.2 x^{*}$ & 91 & $1159 \mathrm{~A}$ \\
\hline & & & & 2015 (AY) & & & & & \\
\hline 0 & $894+41.9 x^{*}$ & 95 & $980 \mathrm{~d}$ & $836+43.3 x^{*}$ & 92 & $958 \mathrm{e}$ & $1166+41.5 x^{*}$ & 96 & $925 \mathrm{~d}$ \\
\hline 30 & $1343+67.8 x^{*}$ & 90 & $1938 \mathrm{c}$ & $1391+62.3 x^{*}$ & 93 & $1036 \mathrm{~d}$ & $1533+60.3 x^{*}$ & 92 & $1605 \mathrm{c}$ \\
\hline 60 & $1576+75.7 x^{*}$ & 91 & $2270 \mathrm{~b}$ & $1846+76.5 x^{*}$ & 91 & $2277 \mathrm{c}$ & $1492+64.7 x^{*}$ & 90 & $1734 \mathrm{c}$ \\
\hline 90 & $1621+79.7 x^{*}$ & 92 & $2639 a$ & $2025+82.5 x^{*}$ & 91 & $2583 \mathrm{~b}$ & $1637+72.2 x^{*}$ & 90 & $2169 b$ \\
\hline 120 & $1473+83.6 x^{*}$ & 91 & $2702 \mathrm{a}$ & $1970+85.8 x^{*}$ & 91 & $2711 \mathrm{a}$ & $1729+79.4 x^{*}$ & 91 & $2453 \mathrm{a}$ \\
\hline General & $1381+69.7 x^{*}$ & 90 & $2106 \mathrm{~A}$ & $1613+70.0 x^{*}$ & 89 & $2093 \mathrm{~A}$ & $1511+63.6 x^{*}$ & 93 & $1777 \mathrm{~B}$ \\
\hline & & & & $2016(\mathrm{FY})$ & & & & & \\
\hline 0 & $2402+80.2 x^{*}$ & 97 & $1473 \mathrm{~d}$ & $2516+78.2 x^{*}$ & 97 & $1406 \mathrm{e}$ & $2438+70.8 x^{*}$ & 95 & $1380 \mathrm{e}$ \\
\hline 30 & $2785+105.1 x^{*}$ & 95 & $2660 \mathrm{c}$ & $2770+93.2 x^{*}$ & 99 & $2241 \mathrm{~d}$ & $2709+87.0 x^{*}$ & 97 & $2178 \mathrm{~d}$ \\
\hline 60 & $3177+108.6 x^{*}$ & 94 & $2730 \mathrm{c}$ & $3455+109.3 x^{*}$ & 99 & $2843 c$ & $2573+92.9 x^{*}$ & 98 & $2748 \mathrm{c}$ \\
\hline 90 & $3132+116.3 x^{*}$ & 94 & $3193 \mathrm{~b}$ & $3266+113.4 x^{*}$ & 96 & $3161 \mathrm{~b}$ & $2903+107.5 x^{*}$ & $\begin{array}{l}90 \\
93\end{array}$ & $3031 \mathrm{~b}$ \\
\hline 120 & $2694+119.6 x^{*}$ & 96 & 3641 a & $3625+127.7 x^{*}$ & 96 & $3624 \mathrm{a}$ & $3340+119.9 \mathrm{x}^{*}$ & 98 & $3373 \mathrm{a}$ \\
\hline General & $2838+105.9 \mathrm{x}^{*}$ & 95 & $2740 \mathrm{~A}$ & $3126+104.3 x^{*}$ & 98 & $2655 \mathrm{~A}$ & $2792+95.6 x^{*}$ & 96 & $2542 \mathrm{~B}$ \\
\hline & & & & 2017 (UY) & & & & & \\
\hline 0 & $469+23.2 x^{*}$ & 96 & $668 \mathrm{c}$ & $729+30.5 x^{*}$ & 86 & $713 \mathrm{c}$ & $778+29.3 x^{*}$ & 95 & $659 \mathrm{~d}$ \\
\hline 30 & $786+34.1 x^{*}$ & 91 & $1031 \mathrm{~b}$ & $826+36.7 x^{*}$ & 91 & $1122 \mathrm{~b}$ & $707+32.7 \mathrm{x}^{*}$ & 90 & $1001 \mathrm{c}$ \\
\hline 60 & $908+41.2 \mathrm{x}^{*}$ & 91 & $1137 \mathrm{~b}$ & $1243+47.9 x^{*}$ & 90 & $1233 \mathrm{~b}$ & $987+36.5 x^{*}$ & 97 & $1157 \mathrm{~b}$ \\
\hline 90 & $1465+59.1 x^{*}$ & 89 & 1441 a & $1188+50.4 x^{*}$ & 90 & $1341 \mathrm{a}$ & $1177+46.9 x^{*}$ & 90 & $1206 \mathrm{a}$ \\
\hline 120 & $1580+58.6 x^{*}$ & 93 & $1357 \mathrm{a}$ & $1419+56.6 x^{*}$ & 92 & $1380 \mathrm{a}$ & $1640+59.3 x^{*}$ & 91 & $1361 \mathrm{a}$ \\
\hline General & $1041+43.2 x^{*}$ & 89 & $1127 \mathrm{~A}$ & $1081+44.4 x^{*}$ & 88 & $1158 \mathrm{~A}$ & $1058+40.9 x^{*}$ & 90 & $1077 \mathrm{~A}$ \\
\hline & & & & & & & & & \\
\hline 0 & $2381+85.5 x^{*}$ & 93 & $1618 d$ & $2509+80.9 \mathrm{x}^{*}$ & 98 & $1538 \mathrm{e}$ & $2842+76.9 x^{*}$ & 93 & $1639 \mathrm{~d}$ \\
\hline 30 & $3262+97.9 x^{*}$ & 95 & $2491 \mathrm{c}$ & $3402+97.4 x^{*}$ & 95 & $2108 \mathrm{~d}$ & $3212+93.9 x^{*}$ & 96 & $1899 \mathrm{~d}$ \\
\hline 60 & $3615+103.9 x^{*}$ & 93 & $2822 b$ & $2923+100.1 x^{*}$ & 99 & $2557 \mathrm{c}$ & $3196+98.9 x^{*}$ & 96 & $2263 \mathrm{c}$ \\
\hline 90 & $3602+109.2 x^{*}$ & 98 & $2973 \mathrm{~b}$ & $3163+100.9 x^{*}$ & 98 & $2810 \mathrm{~b}$ & $3210+95.2 x^{*}$ & 97 & $2615 b$ \\
\hline 120 & $4605+124.4 x^{*}$ & 94 & $3404 \mathrm{a}$ & $3419+118.4 x^{*}$ & 98 & $3385 \mathrm{a}$ & $3810+115.9 x^{*}$ & 98 & $2949 \mathrm{a}$ \\
\hline General & $3493+104.2 x^{*}$ & 98 & $2661 \mathrm{~A}$ & $3083+99.5 \mathrm{x}^{*}$ & 99 & $2480 \mathrm{~B}$ & $3254+96.1 x^{*}$ & 97 & $2273 \mathrm{C}$ \\
\hline
\end{tabular}

$\mathrm{AY}=$ Acceptable year; FY = Favorable year; $\mathrm{UY}=$ Unfavorable year; $\mathrm{N}=$ Nitrogen doses $\left(\mathrm{kg} \mathrm{ha}^{-1}\right) ; \mathrm{V} 3=$ Full condition $(100 \%)$ of the nitrogen dose in the third expanded leaf; V3/V6 = Fractionated condition $(70 \% / 30 \%)$ of the nitrogen dose in the third and sixth expanded leaf; V3/R1 = Fractionated condition $(70 \% / 30 \%)$ of the nitrogen dose in the third expanded leaf and ear differentiation; $\overline{\mathrm{X}}_{\mathrm{GY}}=$ Average grain yield $\left(\mathrm{Kg} \mathrm{ha}^{-1}\right) ; \mathrm{BY}=$ Biomass yield $\left(\mathrm{kg} \mathrm{ha}^{-1}\right) ; \mathrm{R}^{2}=$ coefficient of determination; ${ }^{*}=$ significant at $5 \%$ probability of error, by $\mathrm{t}$ test; Averages followed by the same lowercase letter in the column and uppercase letters in the row, constitute a statistically homogeneous group by the Scott \& Knott model at $5 \%$ of the probability of error.

These authors emphasize that the complex relationships of the plant, climate and management, must be considered in the definition of more efficient and sustainable 
management in the supply of nitrogen. Studies by Costa et al. (2017), in soybean/wheat and corn/wheat systems indicated greater efficiency of nitrogen use in wheat with the nutrient fractionation in the $V_{3} / V_{6}$ stage in a year unfavorable to growing and, when in a favorable agricultural year condition, the supply in a single dose at stage $V_{3}$ was the most indicated. This study also showed that fractionation at the $V_{3} / R_{1}$ stage does not promote benefits for the development of yield indicators, but it can contribute to characteristics of technological quality and chemical composition of the grains.

In Tables 4 and 5, models that seek to validate the expression behavior of wheat grain yield by the maximum technical and economic efficiency of nitrogen use and the expectation of grain yield of $3 \mathrm{t} \mathrm{ha}^{-1}$ are presented, in condition of supply in full and fractionated dose of nitrogen in the different agricultural years. The grain yield estimate by the expectation of $3 \mathrm{t} \mathrm{ha}^{-1}$ was obtained according to the organic matter content of the soil and the succession system. Therefore, in the condition of greater $\mathrm{N}$-residual release (soybean/wheat system) the dose for this expectation is $60 \mathrm{~kg} \mathrm{ha}^{-1}$ of nitrogen. In the system of reduced N-residual release (corn/wheat system) the dose for this same expectation is 80 $\mathrm{kg} \mathrm{ha}^{-1}$ of the nutrient.

Table 4. Maximum technical, economic and yield expectation efficiency of $3 \mathrm{tha}^{-1}$ of wheat under nitrogen use conditions in the soybean/wheat succession system.

\begin{tabular}{|c|c|c|c|c|c|c|c|c|c|}
\hline \multirow{2}{*}{ Year } & \multirow{2}{*}{$\begin{array}{l}\text { Model } \\
G Y=b_{0} \pm b_{1} x \pm b_{2} x^{2}\end{array}$} & \multirow{2}{*}{$\begin{array}{l}\mathrm{P} \\
\left(\mathrm{b}_{\mathrm{i}} \mathrm{x}^{\mathrm{n}}\right) \\
\end{array}$} & \multirow{2}{*}{$\begin{array}{l}\mathrm{R}^{2} \\
(\%)\end{array}$} & \multicolumn{3}{|c|}{$\mathrm{N}\left(\mathrm{kg} \mathrm{ha}^{-1}\right)$} & \multicolumn{3}{|c|}{ GY $\left(\mathrm{kg} \mathrm{ha}^{-1}\right)$} \\
\hline & & & & MTE & MEE & $3 \mathrm{t} \mathrm{ha}^{-1}$ & MTE & MEE & $3 \mathrm{t} \mathrm{ha}^{-1}$ \\
\hline \multicolumn{10}{|c|}{ Full dose $\left(\mathrm{V}_{3}\right)$} \\
\hline $2012(\mathrm{AY})$ & $1773+9.5 x$ & $*$ & 90 & - & - & \multirow{7}{*}{60} & - & - & 2343 \\
\hline 2013 (FY) & $2188+23.9 x$ & $*$ & 95 & - & - & & - & - & 3622 \\
\hline 2014 (UY) & $1140+14.2 x-0.08 x^{2}$ & $*$ & 70 & 88 & 57 & & 1770 & 1689 & 1704 \\
\hline 2015 (AY) & $1548+27.5 x-0.12 x^{2}$ & $*$ & 94 & 114 & 93 & & 3123 & 3067 & 2766 \\
\hline $2016(\mathrm{FY})$ & $2600+24.5 x-0.14 x^{2}$ & $*$ & 76 & 87 & 69 & & 3671 & 3623 & 3566 \\
\hline 2017 (UY) & $1369+14.1 x-0.08 x^{2}$ & $*$ & 79 & 88 & 56 & & 1990 & 1907 & 1927 \\
\hline 2018 (FY) & $2239+24.2 x-0.13 x^{2}$ & $*$ & 95 & 93 & 73 & & 3365 & 3320 & 3223 \\
\hline General & $1809+21.5 x-0.09 x^{2}$ & $*$ & 99 & 119 & 91 & 60 & $3093 \mathrm{Aa}$ & $3020 \mathrm{Aa}$ & $2775 \mathrm{Ba}$ \\
\hline \multicolumn{10}{|c|}{ Fractionated dose $\left(\mathrm{V}_{3} / \mathrm{V}_{6}\right)$} \\
\hline $2012(\mathrm{AY})$ & $1583+20.6 x-0.09 x^{2}$ & $*$ & 89 & 114 & 86 & \multirow{7}{*}{60} & 2762 & 2689 & 2495 \\
\hline 2013 (FY) & $2101+22.9 x$ & $*$ & 95 & - & - & & - & - & 3475 \\
\hline 2014 (UY) & $937+19.3 x-0.12 x^{2}$ & $*$ & 87 & 80 & 59 & & 1713 & 1658 & 1663 \\
\hline 2015 (AY) & $1618+13.8 x$ & $*$ & 92 & - & - & & - & - & 2446 \\
\hline $2016(\mathrm{FY})$ & $2636+18.1 x-0.09 x^{2}$ & * & 86 & 100 & 72 & & 3546 & 3473 & 3398 \\
\hline 2017 (UY) & $1445+15.5 x-0.09 x^{2}$ & $*$ & 80 & 86 & 58 & & 2112 & 2041 & 2051 \\
\hline $2018(\mathrm{FY})$ & $2582+10.6 x$ & $*$ & 80 & - & - & & - & - & 3218 \\
\hline General & $1777+21.7 x-0.09 x^{2}$ & $*$ & 99 & 120 & 93 & 60 & $3085 \mathrm{Aa}$ & $3017 \mathrm{Aa}$ & $2755 \mathrm{Ba}$ \\
\hline \multicolumn{10}{|c|}{ Fractionated dose $\left(\mathrm{V}_{3} / \mathrm{R}_{1}\right)$} \\
\hline $2012(\mathrm{AY})$ & $1691+10.7 x$ & $*$ & 88 & - & - & \multirow{7}{*}{60} & - & - & 2333 \\
\hline 2013 (FY) & $1970+21.2 x$ & $*$ & 93 & - & - & & - & - & 3242 \\
\hline 2014 (UY) & $995+13.1 x-0.06 x^{2}$ & $*$ & 80 & 109 & 67 & & 1710 & 1603 & 1565 \\
\hline 2015 (AY) & $1579+13.4 x$ & $*$ & 93 & - & - & & - & - & 2383 \\
\hline 2016 (FY) & $2463+18.9 x-0.09 x^{2}$ & $*$ & 85 & 105 & 77 & & 3455 & 3384 & 3273 \\
\hline 2017 (UY) & $1306+7.7 x-0.04 x^{2}$ & $*$ & 50 & 96 & 33 & & 1676 & 1516 & 1624 \\
\hline 2018 (FY) & $2383+19.7 x-0.10 x^{2}$ & $*$ & 81 & 98 & 73 & & 3353 & 3288 & 3205 \\
\hline General & $1845+9.9 \mathrm{x}$ & $*$ & 92 & - & - & 60 & - & - & $2439 \mathrm{~b}$ \\
\hline \multicolumn{10}{|c|}{ 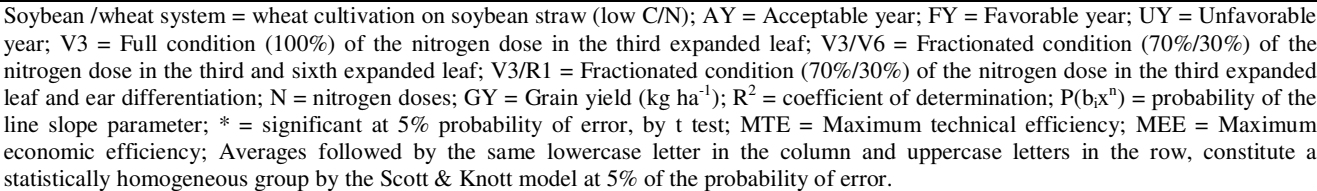 } \\
\hline
\end{tabular}


In Table 4, of the soybean/wheat system, regardless of the condition of the agricultural year, the maximum technical efficiency of nitrogen use in full and fractional doses was close to $120 \mathrm{~kg} \mathrm{ha}^{-1}$, for a grain yield of around $3090 \mathrm{~kg} \mathrm{ha}^{-1}$. The estimation by the model of the maximum economic efficiency allowed to reduce the nitrogen dose to around $90 \mathrm{~kg} \mathrm{ha}^{-1}$, with similarity of grain yield. In addition, the use of a dose of $60 \mathrm{~kg} \mathrm{ha}^{-1}$ of nitrogen for the expectation of $3 \mathrm{t} \mathrm{ha}^{-1}$ (technical indication of wheat), showed a reduction of more than $60 \mathrm{~kg} \mathrm{ha}^{-1}$ of nitrogen compared to the maximum technical efficiency dose. Although the delivered dose of $60 \mathrm{~kg} \mathrm{ha}^{-1}$ of nitrogen decreased yield, it showed a reduction in no more than $300 \mathrm{~kg} \mathrm{ha}^{-1}$. In the fractionated nitrogen condition in $\mathrm{V}_{3} / \mathrm{R}_{1}$, in general, the linear behavior on grain yield is observed, although in some years the behavior is quadratic. However, due to the maximum technical and economic efficiency and expectation of $3 \mathrm{tha}{ }^{-1}$, the similarity of yield in $V_{3}$ and $V_{3} / V_{6}$ was obtained, with reduced yield in $V_{3} / R_{1}$. It is worth mentioning that the application of nitrogen in $V_{3} / V_{6}$ requires a second input to supply the nutrient in the field, resulting in labor and operating costs. Therefore, the need to use nitrogen in full dose at the $\mathrm{V}_{3}$ stage is evident, considering elements such as soil fertility, management and weather conditions in the search for satisfactory yield and less use of nitrogen, a condition that promotes cost reduction and less pollution to the environment.

In Table 5 of the corn/wheat system, the supply condition in $\mathrm{V}_{3}$, in general, showed a quadratic trend with a maximum technical efficiency at $118 \mathrm{~kg} \mathrm{ha}^{-1}$ and economic efficiency with $95 \mathrm{~kg} \mathrm{ha}^{-1}$ of nitrogen. Therefore, the reduction in nitrogen use due to economic efficiency was around $23 \mathrm{~kg} \mathrm{ha}^{-1}$ of nitrogen, with similarity between yields. When analyzing the added value of $80 \mathrm{~kg} \mathrm{ha}^{-1}$ considering the expectation for $3 \mathrm{t} \mathrm{ha}^{-1}$ of grains, a reduction of almost $30 \mathrm{~kg} \mathrm{ha}^{-1}$ of the nutrient is observed. It is noteworthy that in this condition (corn/wheat system), the values obtained for maximum technical, economic efficiency and the expectation of $3 \mathrm{t} \mathrm{ha}^{-1}$ were similar, allowing a great reduction in the use of $\mathrm{N}$-fertilizer, with the possibility of satisfactory yield. In addition, the conditions analyzed by the expectation of $3 \mathrm{tha}^{-1}$ showed greater yield when the nutrient is supplied in full dose, showing that the succession system has reflexes not only on the dose, but also on the efficiency of use of the nutrient by the form of supply. The results presented show that the nitrogen use efficiency can be substantially elevated or reduced by the form of application, along with the meteorological conditions during fertilization and during the growing cycle.

Nitrogen fertilization is quite usual and important in wheat crop, however, determining dosages and the most efficient conditions of use is a challenge in production systems (Mantai et al., 2016; Barbosa et al., 2016). The possibility of analyzing the behavior and simulations of the nutrient in the productivity biomass and grains can qualify more efficient and sustainable managements (Costa et al., 2018; Mamann et al., 2020). The definition of the $\mathrm{N}$-fertilizer dose is a function of the organic matter content of the soil, the previous crop and the grain yield expectations (Mantai et al., 2016; Marolli et al., 2017). On the other hand, the most propitious time for top dressing falls only on the phenology of the plant linked to the period of greatest nutrient demand for the formation of yield components (Bredemeier et al., 2013; Pereira et al., 2018). The technical indications for wheat and oats in Brazil recommend the fertilization time between the beginning of the tillering (stage $V_{3}$ ) and the beginning of the elongation (stage $\mathrm{V}_{6}$ ), an interval around 30 to 60 days after plant emergence (Arenhardt et al., 2015; Marolli et al., 2017). In oats, Mantai et al. (2015) state that the maximum efficiency of nitrogen fertilization in top dressing is obtained when 
applied at the stage of 3 to 4 leaves with the total dose supplied from 70 to $90 \mathrm{~kg} \mathrm{ha}^{-1}$ of nitrogen, this variation being dependent on the temperature and moisture conditions of the soil at the time of fertilization. The nitrogen fractionation has been recommended for providing greater efficiency in the assimilation of nitrogen, especially when the weather conditions are not suitable for the application (Sangoi et al., 2007; Mantai et al., 2016). Studies indicate that the supply of fractionated nitrogen can reduce its losses using partial doses at suitable times for fertilization, especially when the environmental conditions for single dose fertilization in topdressing are not favorable (Brezolin et al., 2016; Reginatto et al., 2021). Costa et al. (2017) observed a greater increase in biomass yield in wheat due to nitrogen fractionation in the phenological stage $\mathrm{V}_{3} / \mathrm{V}_{6}$. In the expression of grain yield, the supply in a single dose increases grain yield in a year favorable to growing, in unfavorable years, the fractionation in the $\mathrm{V}_{3} / \mathrm{V}_{6}$ stage is the most suitable.

Table 5. Maximum technical, economic and yield expectation efficiency of $3 \mathrm{tha}^{-1}$ of wheat under nitrogen use conditions in the corn/wheat succession system.

\begin{tabular}{|c|c|c|c|c|c|c|c|c|c|}
\hline \multirow{2}{*}{ Ano } & \multirow{2}{*}{$\begin{array}{l}\text { Model } \\
G Y=b_{0} \pm b_{1} x \pm b_{2} x^{2}\end{array}$} & \multirow{2}{*}{$\begin{array}{l}\mathrm{P} \\
\left(\mathrm{b}_{\mathrm{i}} \mathrm{x}^{\mathrm{n}}\right)\end{array}$} & \multirow{2}{*}{$\begin{array}{l}\mathrm{R}^{2} \\
(\%)\end{array}$} & \multicolumn{3}{|c|}{$\mathrm{N}\left(\mathrm{kg} \mathrm{ha}^{-1}\right)$} & \multicolumn{3}{|c|}{ GY $\left(\mathrm{kg} \mathrm{ha}^{-1}\right)$} \\
\hline & & & & MTE & MEE & $3 \mathrm{tha}^{-1}$ & MTE & MEE & $3 \mathrm{tha}^{-1}$ \\
\hline \multicolumn{10}{|c|}{ Full dose $\left(\mathrm{V}_{3}\right)$} \\
\hline $2012(\mathrm{AY})$ & $924+34.4 x-0.17 x^{2}$ & $*$ & 96 & 101 & 86 & \multirow{7}{*}{80} & 2664 & 2625 & 2588 \\
\hline $2013(\mathrm{FY})$ & $1603+21.6 x$ & $*$ & 91 & - & - & & - & - & 3331 \\
\hline 2014 (UY) & $819+12.9 x-0.06 x^{2}$ & $*$ & 87 & 107 & 65 & & 1512 & 1404 & 1467 \\
\hline 2015 (AY) & $1026+30.5 x-0.14 x^{2}$ & $*$ & 96 & 109 & 90 & & 2687 & 2637 & 2570 \\
\hline 2016 (FY) & $1765+16.2 x$ & $*$ & 85 & - & - & & - & - & 3061 \\
\hline 2017 (UY) & $769+5.9 x$ & $*$ & 79 & - & - & & - & - & 1241 \\
\hline 2018 (FY) & $1850+13.5 x$ & $*$ & 83 & - & - & & - & - & 2930 \\
\hline General & $1148+26.1 \mathrm{x}-0.11 \mathrm{x}^{2}$ & $*$ & 98 & 118 & 95 & 80 & $2696 \mathrm{~A}$ & $2634 \mathrm{~A}$ & $2532 \mathrm{Aa}$ \\
\hline \multicolumn{10}{|c|}{ Fractionated dose $\left(\mathrm{V}_{3} / \mathrm{V}_{6}\right)$} \\
\hline $2012(\mathrm{AY})$ & $987+32.1 x-0.14 x^{2}$ & $*$ & 97 & 114 & 96 & \multirow{7}{*}{80} & 2827 & 2778 & 2659 \\
\hline 2013 (FY) & $1559+21.8 x$ & $*$ & 95 & - & - & & - & - & 3303 \\
\hline 2014 (UY) & $580+20.5 x-0.11 x^{2}$ & $*$ & 90 & 93 & 70 & & 1535 & 1476 & 1516 \\
\hline 2015 (AY) & $1014+30.3 x-0.14 x^{2}$ & $*$ & 98 & 108 & 90 & & 2653 & 2607 & 2542 \\
\hline 2016 (FY) & $1584+17.8 x$ & $*$ & 94 & - & - & & - & - & 3008 \\
\hline 2017 (UY) & $746+12.9 x-0.07 x^{2}$ & * & 70 & 92 & 91 & & 1340 & 1340 & 1330 \\
\hline 2018 (FY) & $1600+14.6 x$ & * & 94 & - & - & & - & - & 2768 \\
\hline General & $1270+13.6 x$ & $*$ & 93 & - & - & 80 & - & - & $2358 \mathrm{~b}$ \\
\hline \multicolumn{10}{|c|}{ Fractionated dose $\left(\mathrm{V}_{3} / \mathrm{R}_{1}\right)$} \\
\hline 2012 (AY) & $981+26.5 x-0.12 x^{2}$ & $*$ & 96 & 110 & 89 & \multirow{7}{*}{80} & 2444 & 2388 & 2333 \\
\hline 2013 (FY) & $1460+16.7 x$ & * & 90 & - & - & & - & - & 2796 \\
\hline 2014 (UY) & $653+13.6 x-0.06 x^{2}$ & $*$ & 94 & 113 & 71 & & 1423 & 1316 & 1357 \\
\hline 2015 (AY) & $1053+12.1 x$ & $*$ & 92 & - & - & & - & - & 2021 \\
\hline $2016(\mathrm{FY})$ & $1574+16.1 x$ & $*$ & 89 & - & - & & - & - & 2862 \\
\hline 2017 (UY) & $755+5.4 x$ & $*$ & 78 & - & - & & - & - & 1187 \\
\hline $2018(\mathrm{FY})$ & $1606+11.1 x$ & $*$ & 90 & - & - & & - & - & 2494 \\
\hline General & $1199+11.5 x$ & $*$ & 96 & - & - & 80 & - & - & $2119 \mathrm{c}$ \\
\hline \multicolumn{10}{|c|}{$\begin{array}{l}\text { Corn/wheat system }=\text { wheat cultivation on corn straw (high } \mathrm{C} / \mathrm{N}) ; \mathrm{AY}=\text { Acceptable year; FY = Favorable year; UY = Unfavorable year; } \\
\mathrm{V} 3=\text { Full condition }(100 \%) \text { of the nitrogen dose in the third expanded leaf; } \mathrm{V} 3 / \mathrm{V} 6=\text { Fractionated condition }(70 \% / 30 \%) \text { of the nitrogen } \\
\text { dose in the third and sixth expanded leaf; } \mathrm{V} 3 / \mathrm{R} 1=\text { Fractionated condition }(70 \% / 30 \%) \text { of the nitrogen dose in the third expanded leaf and } \\
\text { ear differentiation; } \mathrm{N}=\text { nitrogen doses; } \mathrm{GY}=\mathrm{Grain} \text { yield }\left(\mathrm{kg} \mathrm{ha}^{-1}\right) ; \mathrm{R}^{2}=\text { coefficient of determination; } \mathrm{P}\left(\mathrm{b}_{\mathrm{i}} \mathrm{x}^{\mathrm{n}}\right)=\text { probability of the line } \\
\text { slope parameter; } *=\text { significant at } 5 \% \text { probability of error, by t test; MTE = Maximum technical efficiency; MEE = Maximum economic } \\
\text { efficiency; Averages followed by the same lowercase letter in the column and uppercase letters in the row, constitute a statistically } \\
\text { homogeneous oroup by the Scott \& Knott model at 5\% of the probability of error. }\end{array}$} \\
\hline
\end{tabular}

The United Nations Sustainable Development Goals represent an urgent and formidable challenge for scientists and society, due to the urgent need to transform agriculture and the food sector in achieving food security with socio-environmental 
sustainability (Dhankher and Foyer, 2018; Silva et al., 2020). In this context, it is necessary to promote food security based on new concepts, which requires a much broader and systems-based approach, including the environment, technology, economy and society, at all levels of the organization (Nüsslein and Dhankher, 2016; Dornelles et al., 2020).

\section{CONCLUSIONS}

Greater efficiency of use of nitrogen is obtained in the productivity of wheat grains when applied with the full dose at the third expanded leaf phenological stage. The supply of the maximum dose of nitrogen with the expectation of $3 \mathrm{t} \mathrm{ha}^{-1}$, ensures satisfactory productivity with reduced nutrient losses to the environment, mainly in unfavorable years for cultivation, regardless of the succession systems.

\section{ACKNOWLEDGMENTS}

We thank CAPES, CNPq, FAPERGS and UNIJUI for financial support for research and the Scientific and Technological Initiation Scholarship, Post-Graduate Scholarship and Research Productivity Scholarship. We thank the graduate program in Mathematical Modeling and Environmental Systems and Sustainability at UNIJUÍ for the resources available for the development of this research, which was part of the doctoral thesis of the first author.

\section{CONFLICTS OF INTEREST}

The authors declare no conflict of interest.

\section{REFERENCES}

Araus JL, Slafer GA, Royo C and Serret MD (2008). Breeding for yield potential and stress adaptation in cereals. Crit. Rev. Plant. Sci. 27(6): 377-412. https://doi.org/: 10.1080/07352680802467736.

Arenhardt EG, Silva JAG, Gewehr E, Oliveira AC, et al. (2015). The nitrogen supply in wheat cultivation dependent on weather conditions and succession system in southern Brazil. Afr. J. Agric Res. 48(10): 4322-4330. https://doi.org/: 10.5897/AJAR2015.10038.

Arenhardt EG, Silva JAG, Arenhardt LG, Silva DR, et al. (2017). Technical and agronomic efficiency of oat cultivars as a function of nitrogen availability. Científica. 45(3): 257-270. http://dx.doi.org/10.15361/19845529.2017v45n3p257-270.

Barbosa A, Silva AFM, Albrecht LP, Albrecht AJP, et al. (2016). Doses de Nitrogênio em cobertura na produtividade e qualidade fisiológica de sementes de trigo. Magistra. 28(2): 710-719.

Benin G, Bornhofen E, Beche E, Pagliosa ES, et al. (2012). Agronomic performance of wheat cultivars in response to nitrogen fertilization levels. Acta. Sci. Agron. 34(3): 275-283. https://doi.org/: 10.1590/S180786212012000300007.

Bredemeier C, Variani C, Almeida DP and Rosa AT (2013). Estimativa do potencial produtivo em trigo utilizando sensor óptico ativo para adubação nitrogenada em taxa variável. Cienc. Rural. 43(7): 1147-1154. https://doi.org/: 10.1590/S0103-84782013005000080.

Brezolin AP, Silva JAG, Roos-Frantz FC, Binelo MO, et al. (2016). The efficiency of wheat yields by nitrogen dose and fractionation. Afri. J. Agric. Res. 11: 3440-3449. https://doi.org/10.5897/AJAR2016.11249.

Camponogara AS, Oliveira GA, Georgin J and Rosa ALD (2016). Avaliação dos componentes de rendimento do trigo quando submetido a diferentes fontes de nitrogênio. Rev Elet. Gest. Educ. Tecnol. Ambient. 2(1): $524-532$. https://doi.org/: 10.5902/2236117019723.

Caron BO, Oliveira DM, Elli EF, Eloy E, et al. (2017). Elementos meteorológicos sobre características morfológicas e produtivas do milho em diferentes épocas de semeadura. Científica. 45(2): 105-114. https://doi.org/: $10.15361 / 1984-5529.2017 \mathrm{v} 45 \mathrm{n} 2 \mathrm{p} 105-114$. 
Carvalho IR, Silva JAG, Ferreira LL, Bubans VE, et al. (2019). Heritability profiles defined by hierarchal models and artificial neural networks for dual-purpose wheat attributes. Genet. Mol. Res. 18(3): GMR18266. https://doi.org/: $10.4238 / \mathrm{gmr} 18266$

Cordeiro MB, Dallacort R, Freitas PSL, Seabra Junior S, et al. (2015). Aptidão agroclimática do trigo para as regiões de Rondonópolis, São José do Rio Claro, São Vicente e Tangará da Serra, Mato Grosso, Brasil. Ver. Agroamb. 9(1): 96-101. https://doi.org/: 10.18227/1982-8470ragro.v9i1.2177.

Costa JSP, Mantai RD, Silva JAG, Scremin AH, et al. (2017). Single and fractioned supply of nitrogen in wheat productivity. Int. J. Dev. Res. 7(6): 13055-13061

Costa JSP, Mantai RD, Silva JAG, Scremin OB, et al. (2018). Single and split nitrogen dose in wheat yield indicators. Rev. Bras. Eng. Agr. Amb. 22(1): 16-21. https://doi.org/: 10.1590/1807-1929/agriambi.v22n1p16-21.

Cruz CD (2006). Programa GENES: Estatística experimental e matrizes. Viçosa, UFV.

Dhankher OP and Foyer CH (2018). Climate resilient crops for improving global food security and safety. Plant Cell. Environ. 41(1): 877-884. https://doi.org/: 10.1111/pce.13207.

Dornelles EF, Silva JAG, Carvalho IR, Alessi O, et al. (2020). Resistance of oat cultivars to reduction in fungicide use and a longer interval from application to harvest to promote food security. Genet. Mol. Res. 19(2): GMR18542. https://doi.org/: 10.4238/gmr18542.

Ercoli L, Masoni A, Pampana S, Mariotti M, et al. (2013). As durum wheat productivity is affected by nitrogen fertilisation management in Central Italy. Eur. J. Agron. 44(1): 38-45. https://doi.org/: 10.1016/j.eja.2012.08.005.

Ferrari M, Nardino M, Carvalho IR, Szareski VJ, et al. (2016). Manejos e fontes de nitrogênio nos componentes de afilhamento de trigo. Rev. Bras. Ciênc Agrár. 11(1): 178-185. https://doi.org/: 10.5039/agraria.v11i3a5379.

Goergen PCH, Krüger CAMB, Bianchi V, Silva IW, et al. (2017). Effects of Schinus terebinthifolius extracts on the control of Sitophilus species in stored wheat grains. Afr. J. Agric Res. 12(51): 3556-3561. https://doi.org/ 10.5897/AJAR2017.12621.

Guarienti EM, Ciacco CF, Cunha GR, Del LJ, et al. (2004). Influência das temperaturas mínima e máxima em características e qualidade industrial e em rendimento de grãos de trigo. Cienc. Tecnol. Aliment. 24(4): 505-515. https://doi.org/: 10.1590/S0101-20612004000400005.

Heinemann AB, Stone LF, Didonet AD, Trindade MG, et al. (2006). Eficiência de uso da radiação solar na produtividade do trigo decorrente da adubação nitrogenada. Rev. Bras. Eng. Agr. Amb. 10(2): 352-356. https://doi.org/: 10.1590/S1415-43662006000200015.

Ladha JK, Tirol-Padre A, Reddy CK, Cassman KG, et al. (2016). Global nitrogen budgets in cereals: A 50-year assessment for maize, rice, and wheat production systems. Sci. Rep. 6(1): 19355. https://doi.org/: $10.1038 /$ srep 19355

Liang X, Rashidi M, Rogers CW, Marshall JM, et al. (2019). Winter wheat (Triticum aestivum) response to Barley yellow dwarf virus at various nitrogen application rates in the presence and absence of its aphid vector, Rhopalosiphum padi. Entomol. Exp. Appl. 167(1): 98-107. https://doi.org/: 10.1111/eea.12748.

Luche HS, Silva JAG, Maia LC and Oliveira AC (2015). Stay-green: a potentiality in plant breeding. Cienc. Rural. 45(10): 1755-1760. https://doi.org/: 10.1590/0103-8478cr20140662.

Luche HS, Silva JAG, Nornberg R, Arenhardt EG, et al. (2017). Prediction of parental combination for introduction of stay-green associated loci in Wheat. J. Crop Sci. Biotechnol. 20(2): 73-80. https://doi.org/: 10.1007/s 12892-0160127-0.

Mamann ATW, Silva JAG, Scremin OB, Mantai RD, et al. (2017a). The combination of hydrogel and nitrogen in wheat grain productivity. Int. J. Dev. Res. 7(6): 13088-13094.

Mamann ATW, Silva JAG, Scremin OB, Mantai RD, et al. (2017b). Nitrogen efficiency in wheat yield through the biopolymer hydrogel. Rev. Bras. Eng. Agr. Amb. 21(10): 697-702. https://doi.org/10.1590/18071929/agriambi.v21n10p697-702.

Mamann ATW, Silva JAG, Binelo MO, Scremin OB, et al. (2019). Artificial intelligence simulating grain productivity during the wheat development considering biological and environmental indicators. J. Agric. Stud. 7(3): 197-212. https://doi.org/10.5296/jas.v7i315153.

Mamann ATW, Silva JAG, Scremin OB, Trautmann APB, et al. (2020). Diffuse system simulating wheat productivity by nitrogen and temperature in the use of biopolymers. Rev. Bras. Eng. Agr. Amb. 24(5): 289-297. https://doi.org/: 10.1590/1807-1929/agriambi.v24n5p289-297.

Mandal S, Thangarajan R, Bolan NS, Sarkar B, et al. (2016). Biochar-induced concomitant decrease in ammonia volatilization and increase in nitrogen use efficiency by wheat. Chemosphere. 142(1): 120-127. https://doi.org/: 10.1016/j.chemosphere.2015.04.086.

Mantai RD, Silva JAG, Sausen ATZR, Costa JSP, et al. (2015). A eficiência na produção de biomassa e grãos de aveia pelo uso do nitrogênio. Rev. Bras. Eng. Agr. Amb. 19(4): 343-349. https://doi.org/: 10.1590/18071929/agriambi.v19n4p343-349.

Mantai RD, Silva JAG, Arenhardt EG, Sausen ATZR, et al. (2016). The dynamics of relation oat panicle with grain yield by nitrogen. Am. J. Plant. Sci. 7: 17-27. http://dx.doi.org/10.4236/ajps.2016.71003.

Marolli, A, Silva JAG, Mantai RD, Brezolin AP, et al. (2017). Oat yield through panicle components and growth regulator. Rev. Bras. Eng. Agr. Amb. 21(4): 261-266. https://doi.org/10.1590/1807-1929/agriambi.v21n4p261-266. 
Nornberg R, Silva JAG, Luche HS, Tessmann EW, et al. (2015). Tolerance to preharvest sprouting and yield of wheat genotypes from different breeding programs. Pesq. Agropec. Bras. 50(8): 698-706. https://doi.org/: 10.1590/S0100204 X2015000800008.

Nusselein K and Dhankher OP (2016). Project management: food security needs social-science imput. Nature. 535(1): 37-37. https://doi.org/: 10.1038/535037d.

Pennacchi JP, Carmo-Silva E, Andralojc PJ, Lawson T, et al. (2018). Stability of wheat grain yields over three field seasons in the UK. Food Energy Secur. 8(1): e00147. https://doi.org/: 10.1002/fes3.147.

Pereira LM, Tissot-Squalli ML, Wildner G, Dornelles EF, et al. (2018). Oxidative stress measurements can indicate the best dose and period of nitrogen fertilizer in white oat crop. Int. J. Dev. Res. 8(1): 18468-18474.

Petean CC, Teixeira Filho MCM, Galindo FS, Buzetti S, et al. (2019). Polímeros orgânicos com ureia dissolvida e doses de nitrogênio no milho. Rev. Cienc. Agrar. 62(1): 1-9. https://doi.org/: 10.22491/rca.2019.2761.

Reginatto DC, Silva JAG, Carbonera R, Menegassi CAB, et al. (2021). Sustainable optimization of nitrogen uses in oat at sowing and top-dressing stages. Afr. J. Agric Res. 15(1): 23-31. https://doi.org/: 10.21475/ajcs.21.15.01.2333.

Ribeiro G, Pimente AJB, Souza MA, Rocha JRASC, et al. (2012). Estresse por altas temperaturas em trigo: impacto no desenvolvimento e mecanismos de tolerância. Rev. Bras. Agrocienc. 18(2): 133-142. https://doi.org/: 10.18539/cast.v18i2.2502.

Ronsani SC, Piva JT, Fioreze S, Basso KC, et al. (2018). Adubação nitrogenada na produção de grãos e matéria seca de cultivares de trigo de duplo propósito. Rev. Cienc. Agrovet. 17(2): 174-181. https://doi.org/: $10.5965 / 223811711722018174$.

Sangoi L, Berns AC, Almeida ML, Zanin CG, et al. (2007). Características agronômicas de cultivares de trigo em resposta a época da adubação nitrogenada de cobertura. Cienc. Rural. 37(6): 1564-1570. https://doi.org/: 10.1590/S0103-84782007000600010.

Scremin OB, Silva JAG, Mamann ATW, Mantai RD, et al. (2017). Nitrogen efficiency in oat yield through the biopolymer hydrogel. Rev. Bras. Eng. Agr. Amb. 21(10): 379-385. https://doi.org/: 10.1590/18071929/agriambi.v21n10p697-702.

Shewry PR (2007). Improving the protein content and composition of cereal grain. J. Cereal Sci. 46 (3): $239-250$. https://doi.org/: 10.1016/j.jcs.2007.06.006.

Silva JAG, Arenhardt EG, Krüger CAMB, Lucchese OA, et al. (2015). A expressão dos componentes de produtividade do trigo pela classe tecnológica e aproveitamento de nitrogênio. Rev. Bras. Eng. Agr. Amb. 19(1): 27-33. https://doi.org/: 10.1590/1807-1929/agriambi.v19n1p27-33.

Silva JAG, Neto CJG, Fernanes SBV, Mantai RD, et al. (2016). Nitrogen efficiency in oats on grain yield with stability. Rev. Bras. Eng. Agr. Amb. 20(12): 1095-1100. https://doi.org/: 10.1590/1807-1929/agriambi.v20n12p1095-1100.

Silva JAG, Mamann ÂTW, Scremin OB, Carvalho IR, et al. (2020). Biostimulants in the Indicators of Yield and Industrial and Chemical Quality of Oat Grains. J. Agric. Stud. 8(2): 68-87. https://doi.org/: 10.5296/jas.v8i2.15728.

Siqueira Neto M, Piccolo MC, Venzke Filho SP, Feigl BJ, et al. (2010). Mineralização e desnitrificação do nitrogênio no solo sob sistema de plantio direto. Bragantia. 69(4): 923-936. https://doi.org/: 10.1590/S000687052010000400019

Stefen DLV, Souza CA, Coelho CMM, Gutkoski LC, et al. (2015). A adubação nitrogenada durante o espigamento melhora a qualidade industrial do trigo (Triticum aestivum cv. Mirante) cultivado com regulador de crescimento etil trinexapac. Rev. Fac. Agron. 114(2): 161-169.

Tasca FA, Ernani PR, Rogeri DA, Gatiboni LC, et al. (2011). Volatilização de amônia do solo após a aplicação de ureia convencional ou com inibidor de uréase. Rev. Bras. Cienc. Solo. 35(2): 493-502.

Tedesco MJ, Gianello C, Bissani CA, Bohnen H, et al. (1995). Análise de solo, plantas e outros materiais. Boletim técnico. $2^{\mathrm{a}}$ ed. UFRGS, Porto Alegre.

Trautmann APB, Silva JAG, Binelo MO, Valdiero AC, et al. (2020). Simulation of wheat yield by nitrogen and nonlinearity of environmental conditions. Rev. Bras. Eng. Agr. Amb. 24(1): 44-51. https://doi.org/10.1590/18071929/agriambi.v24n1p44-51.

Vasconcellos JPR, Reis RB, Rezende RM, Rezende RAL, et al. (2018). Influência da velocidade de semeadura na produtividade do trigo. Rev. Uni. Vale Rio Verde. 16(3): 1-7. https://doi.org/: 10.5892/ruvrd.v16i3.5601.

Vieira RF (2017). Ciclo do Nitrogênio em Sistemas Agrícolas. Brasília, DF: Embrapa, 163 p.

Wick G, Heumesser C and Schmid E (2012). Groundwater nitrate contamination: Factors and indicators. J. Environ. Manag. 111(1): 178-186. https://doi.org/: 10.1016/j.jenvman.2012.06.030.

Xu G, Fan X and Miller AJ (2012). Plant nitrogen assimilation and use efficiency. Annu Rev. Plant Biol. 63(1): $153-182$. https://doi.org/: 10.1146/annurev-arplant-042811-105532. 